\title{
CERVANTES EN LOS AUTOS SACRAMENTALES DE CALDERÓN
}

Escribía el profesor Wilson ${ }^{1}$ hace más de veinte años, en 1977: "han sido muy pocos los críticos a quienes se les ha ocurrido relacionar al mayor novelista español con uno de los dos más grandes dramaturgos de ese mismo país. Por supuesto, Calderón y Cervantes parecen muy distintos entre sín. Aunque es cierto que durante siglos se han deslizado tópicos estereotipados sobre los dos autores y su diferente concepción del mundo ${ }^{2}$, también es muy cierto, y numerosas veces se olvida, que quienes primero advirtieron una relación más profunda entre ambos fueron los creadores-críticos del fin de siglo, que por caminos distintos a los de la erudición, fueron apuntando esas relaciones iniciales. Con la excepción de aquellos primeros y tímidos acercamientos en vísperas del centenario de Calderón en 1881, de la manó de Lope Damián Ruiz Rodríguez ${ }^{3}$, pocos fueron los que se fijaron en las afinidades de uno y otro autor, y se cometería una grave injusticia si no se reconociese a Unamuno su sensibilidad como iniciador de una rica aventura familiar entre los dos personajes más universales de estos autores.

\footnotetext{
1 «Calderón y Cervantes», en Archivum Calderonianum. Hacia Calderón. Band I, Quinto Coloquio Anglogermano, 1978, pp. 9-19.

2 Wilson recoge en el citado trabajo la visión tradicional que se ha tenido de los dos escritores: "Cervantes tenía una imagen del ser humano positiva y de largo alcance, al tiempo que un gran sentido del humor y numerosos contactos fuera del mundo de las letras. La imagen que Calderón tiene de la sociedad parece a primera vista limitada a la esfera de los hidalgos, los santos, los bandidos, y los sirvientes, y ha habido pocos críticos dispuestos a reconocerle el más mínimo sentido del humor» (op. cit., p. 9)

3 En Cervantes en el centenario de Calderón de la Barca. 1881. Valladolid, Imprenta de Benito Manuel y Leonardo Díez.
} 
Ambos han recorrido en nuestro siglo una trayectoria paralela y ciertamente la revalorización de la obra de Calderón en nuestro siglo sólo se fue fraguando tras la exaltación de la de Cervantes, iniciada a partir de las simbólicas interpretaciones de Schlegel hasta adquirir don Quijote proporciones románticas y universales. El personaje cervantino se fue revitalizando y actualizando en España hasta convertirse en leyenda viva capaz de sufrir los mismos avatares de la historia española que los hombres de su época. A medida que los acontecimientos provocaban un desencanto, los personajes cervantinos se veían contaminados de ese desengaño general ${ }^{4}$.

4 Lógicamente el Desastre del 98, por cuanto supuso de reflexión sobre el "alma» española, reavivó el interés por estos personajes. Sin embargo, ese interés ya había surgido antes de esa fecha como preámbulo de la futura crisis, y ya desde 1895 se utilizó la curación de Don Quijote como símbolo representativo de la regeneración nacional.

La vuelta a la historia del pasado para hallar las causas de la decadencia presente condicionó una visión crítica de la obra más representativa de la ilusión y del desengaño. Por ello no es extraño encontrar juicios tan negativos como el de Maeztu que llegó a considerarla como «el espejo más acabado y la apología más genial de la decadencia, del cansancio de un pueblo». Incluso se aconsejaba a los jóvenes no leer esa obra para no dejarse llevar por la melancolía y el desaliento y por la falta de estímulos que pudiera crear en el lector. En esta línea se explica el grito de Unamuno «iMuera Don Quijote!» en las páginas de Vida Nueva. que resumía la necesidad de hacer triunfar el espíritu de la realidad frente al idealismo soñador encarnado en los personajes cervantinos. Pero también significaba la preocupación por el pueblo, por la intrahistoria olvidada y con ella por el bueno de Alonso Quijano.

Rubén Darío desde sus primeras obras mostró una equilibrada visión de los tres personajes (Alonso el Bueno, Sancho y Don Quijote), pero sobre todo a raíz de sus crónicas tras el Desastre (reunidas en 1901 en España contemporánea) dio una auténtica lección de cómo el idealismo podía convivir con la rebeldía y la crítica de la realidad. En este sentido puede considerarse a Rubén Darío el impulsor auténtico de la recuperación del sentido simbólico pleno que va adquiriendo el personaje cervantino durante nuestro siglo, junto a la fuerza que experimentó en los momentos más conflictivos de nuestra historia, como se ocupó de resaltar Antonio Machado.

Se puede afirmar que las preocupaciones políticas de Rubén Darío, paralelas a su ejercicio del periodismo, bajo la influencia ética de José Martí y Paul Groussac, le sirvieron para hacer de la profesión periodística un medio para educar a la sociedad con la pretensión de transformar la realidad. Lo curioso es que en sus crónicas, artículos, reportajes o semblanzas, Rubén nunca dejó de evocar, analizar y elogiar la figura y obra de Cervantes. A él llegó directamente por sus lecturas desde niño, pero también profundizó más en toda su dimensión por influencia de los escritores de otras nacionalidades. Si el mismo Groussac ya había mostrado su interés por el autor español e incluso por el Quijote de Avellaneda (al que dedicó un libro tratando de explicar su enigma), José Martí, en su defensa de la libertad había mostrado el camino para salvar a Don Quijote. Rubén Darío, como no hizo ningún otro escritor español, ante el triunfo americano volvió los ojos a Cervantes en un gesto de solidaridad con España y sobre todo de consagración de sus propios ideales. Si «El triunfo de Calibán» y «El crepúsculo de España» son represen- 
Las visiones impresionistas de Azorín hacia Cervantes, sobre todo, y la transformación del personaje y autor en tema lírico abrieron una nueva vía de exploración de la obra cervantina que inevitablemente se sentía relacionada (para oponerla en la mayoría de casos con la excepción de Unamuno) con la de Calderón.

Quizá haya que partir de esa doble apoyatura, sentimental y viva, por un lado, y testimonial y crítica por otro, para reunir todos los materiales que permitan relacionar a los dos autores. En este caso no se trata de buscar fuentes concretas para establecer deudas, que las hay ${ }^{5}$, sino de apuntar la elección de algunas ideas y temas como muestra de una preferencia estilística o ideológica procedente del conocimiento directo y gusto del dramaturgo por las obras de Cervantes. Aunque no tengamos los documentos acreditativos de las lecturas de Calderón es casi impensable que un autor de su hondura cultural no conociese su obra, lo mismo que la de Góngora o el Romancero, o los distintos géneros narrativos del XVI y XVII, por ceñirnos sólo a la literatura del momento. Además, por ser dramaturgo le era prácticamente exigido conocer las fuentes ${ }^{6}$ de las que se nutría todo el teatro del Siglo de Oro. De ahí que sea inevitable la repetición de asuntos y temas en la mayoría de los autores aunque el tratamiento de los mismos nunca sea coincidente.

Los gustos del público tampoco permitían elaborar una variedad muy grande y sin embargo la originalidad de los dramaturgos imponía una diferencia esencial pese a utilizar unos mismos esquemas $^{7}$. La rareza del personaje cervantino y la admiración que causó su nacimiento tuvo que repercutir en los creadores y de hecho

tativos de la fuerza de un autor combativo que se resistía a la invasión materialista del mundo, todos sus artículos recogen algo del espíritu cervantino. Puede afirmarse que cualquier sensación (comida, paisaje, fiesta, risa) se traduce en recuerdos de Don Quijote. De todos ellos, en los que prevalece el sentido ideal y soñador, se pueden extraer las características humanas y artísticas que rodearon al propio autor. La comprensión hacia los demás, el esfuerzo en el trabajo, la necesidad de justicia y el valor de los sentimiento están expresados en las páginas de los periódicos en los que colaboró durante toda su existencia errante, de forma paralela a su poesía, con el apoyo de los personajes cervantinos. En esta doble lección, Rubén Darío no sólo equiparó su lengua poética a la más sencilla de la crónica sino que incorporó a la vida cotidiana de los lectores la vivencia constante de Cervantes.

5 Como puede verse con una rápida consulta a las clásicas Concordancias de Calderón o a las más completas ediciones electrónicas.

6 Esas fuentes eran de todo tipo (historia, geografía, arte, música, retórica, jurisprudencia, etc.), como señaló Bances Candamo en su teoría dramática (Teatro de los teatros), a propósito de la dificultad de hacer comedias a diferencia de otros géneros más sencillos que exigían menos conocimientos.

7 Aunque también existía un código común que permitía la escritura de una obra por varios autores sin que en muchos casos la crítica haya podido deslindar la autoría. 
así fue, a juzgar por la descendencia de alusiones, imitaciones e influencias que provocó. Manuel García Martín ${ }^{8}$, siguiendo a Leopoldo Ríus ${ }^{9}$, y recogiendo sus propias palabras, estableció este juicio como punto de partida para su estudio sobre Cervantes y la comedia española en el siglo XVII: "Que el Quijote, y las Novelas, y varias comedias de Cervantes, eran obras conocidas, apreciadas y popularizadas ya en los tiempos del autor, y siguieron siéndolo durante el siglo XVII lo prueban (...) las citas y menciones que de ellas hicieron en sus producciones los escritores más notables, ya que puede decirse que todos se inspiraron en ellas para sus composiciones dramáticas ${ }^{10}$ ».

Así, junto a la recuperación afectiva por parte de los creadores, los eruditos trabajos de Cayetano de la Barrera, el ya citado de Ríus, los de Cotarelo, A. Bulbena y Tussell, Gabriel Martín Río y Rico, F. Pérez Capo ${ }^{11}$ abrieron un nuevo camino en la investigación cervantina dirigida más concretamente a la relación entre éste con Calderón. Posteriormente Alberto Sánchez ${ }^{12}$, Alberto Navarro, Palacios Rodríguez ${ }^{13}$, Cesáreo Bandera ${ }^{14}$, Ciriaco Morón ${ }^{15}$, Robert Ter Horst $^{16}$, Didier Souiller ${ }^{17}$, José Angel Ascunce ${ }^{18}$, Catalina Buezo ${ }^{19}$, Fernando Cantalapiedra ${ }^{20}$ y Oscar Pereira ${ }^{21}$, entre otros, han concretado algunas de estas relaciones.

8 Cervantes y la comedia española en el siglo XVII. Salamanca, Ediciones de la Universidad, 1980. Reunió bastantes ejemplos de obras dramáticas a partir de la fuente Cervantes aunque faltan muchos casos que no obedecen a una influencia textual.

9 Recogido de Bibliografía crítica de las obras de Miguel de Cervantes. Madrid (1895-1905), t. III, pp.1-2.

10 En op. cit. p.12. La cursiva es nuestra.

11 Una bibliografía más completa sobre el tema en sus inicios puede verse en el trabajo ya citado de Manuel García Martín.

12 "Reminiscencias cervantinas en el teatro de Calderón», en Anales cervantinos, VI, M., 1957, pp. 262-270

13 Don Quijote y La vida es sueño. Madrid, Rialp, 1960.

14 Mímesis conflictiva. Ficción literaria y violencia en Cervantes y Calderón. Madrid, Gredos, 1975.

15 Calderón. Pensamiento y teatro. Santander, Sociedad Menéndez Pelayo, 1982.

16 Calderón. The Secular Plays. Kentucky, The University Press, 1982 (especialmente pp. 69-170).

17 Calderón et le grand théátre du mond. Paris, P.U.F. 1992.

18 «Superposición temática y estructura radial en la literatura del barroco. Novela frente a comedia. Cervantes frente a Calderón». Actas del Congreso Internacional sobre Calderón y el teatro español del Siglo de Oro, III, 1983, pp. 1233-1245.

19 «El rufián viudo llamado Trampagos: una boda burlesca entremesada de Cervantes", en Cervantes. Estudios en la víspera de su centenario, II. Kassel, Reichenberger, 1994, pp. 371-379.

${ }_{20}$ "Las figuras alegóricas en el teatro cervantino», en Cervantes, op. cit., II, pp. 381-399.

${ }^{21}$ "Teatrum mundi: Cervantes y Calderón», en Anales cervantinos, XXVII. Madrid, C.S.I.C., 1989, pp. 187-202. 
En nuestros días, el profesor Regalado ha indagado al hilo de su profundo estudio sobre Calderón acerca de las deudas de éste sobre aquél. Como era de esperar en un dramaturgo con la capacidad de sincretismo y sensibilidad de Calderón, tan preocupado por las claves de la existencia, la huella cervantina no sólo está presente en anécdotas, citas, motivos o temas sino en la percepción del mundo, en el análisis de la conciencia y en el problema de la creencia y la experiencia. La complejidad de la existencia en cuanto diálogo del hombre consigo mismo y con los demás y el mundo exterior, no sólo hizo a Calderón ser, en palabras de Regalado, «el sobresaliente discípulo de Cervantes ${ }^{22}$ », sino constituir entre los dos el pensamiento más original de otro de los autores más preocupados por la esencia y la existencia como es Unamuno. Quizá sea necesario releer a este vasco sin los prejuicios noventayochistas trasnochados para iniciar un camino paralelo de crítica y creación capaz de abrir nuevas vías para mostrar el reconocimiento que Calderón tuvo hacia su antecesor Cervantes y que muy bien fue destacado por el creador de Niebla ${ }^{23}$.

Desde luego hay unas coincidencias generales previas que no tienen nada que ver con relaciones o influencias concretas pero que permiten entender éstas pues revelan una afinidad espiritual previa de la que parten todas lo demás. Lo primero que destaca en los dos autores es el carácter de unidad de toda su obra. Cuando eligen temas y personajes nunca los agotan en una sola pieza sino que sus creadores vuelven reiteradamente sobre ellos para desentrañar y descifrar todos los rincones de su intimidad o ahondar en el alcance de su interpretación ${ }^{24}$.

Si los personajes cervantinos se reencarnan en otros nuevos protagonistas, sus temas también reaparecen una y otra vez en versiones diferentes. La locura o enajenación, el ideal amoroso y personal y los ejemplos tomados de la vida real con sus cotidianos problemas sociales (justicia, honor, celos, marginación social), así

22 Calderón. Los orígenes de la modernidad en la España del Siglo de Oro. Barcelona, Destino, 1995, I, 708.

${ }^{23}$ Sobre todo en la Vida de Don Quijote y Sancho, aunque es un tema inagotable en todos los géneros que abordó.

24 MANUEl GaRcía MARTín resumió algunos ejemplos ilustradores de esta afirmación: «Así, los amigos Timbrio y Silerio de La Galatea se reencarnan con distinta perspectiva en Anselmo y Lotario de El curioso impertinente; el mutismo y recato de Constanza (La ilustre fregona) se convierten en el alegre y desenvuelto actuar de Preciosa (La Gitanilla). La naturalidad y ternura de ésta pasan a transformarse en la vanidad y egoísmo de Belica (Pedro de Urdemalas); Anselmo y Carrizales no son, salvando las distancias, sino dos enajenados quijotes que confunden la realidad; los niños cautivos que sufren y abjuran de su fe en Los tratos de Argel llegan a ser mártires en Los Baños de Argel, etc.» (op. cit., p. 259). 
como la relación del hombre con su obra y con Dios se reiteran constantemente y se resuelven definitivamente en Don Quijote por parte de Cervantes. Sin embargo, aunque en él concentró y resumió su creador cuantos intereses tenía, otros protagonistas (desde los descritos en los romances hasta los diseñados en teatro y novelas ejemplares desde las primeras hasta el postrero Persiles) participan de las mismas cualidades del hidalgo manchego.

En el caso de Calderón puede decirse lo mismo. Los temas de la libertad, la rebeldía, la trascendencia del ser, la voluntad de poder, la fuerza del amor, la dialéctica de la razón y la fe, de la esencia y existencia, de la apariencia y realidad, van dando vida a una gran parte de sus personajes. El título de una de sus primeras comedias, Amor, honor y poder no resulta casual sino simbólico de la fuerza creadora de su autor que a modo de estructura circular representa a todo el conjunto de su obra desde la juventud a la vejez. La misma locura o enajenación de los personajes cervantinos se halla en los mejores protagonistas calderonianos desde Segismundo a Semíramis. En realidad, los dos autores, anticipándose a Sartre, buscaron desde el fondo de su conciencia los caminos de la libertad para llegar a vislumbrar de cerca la eternidad (o la misma condena cuando en lugar del heroísmo virtuoso arriesgaban ciegamente todo por el poder, como ocurre en los de Calderón). Sin embargo, pese al camino de perfección íntima (con una voluntad férrea) que se propusieron sus héroes, nunca abandonaron la realidad. Precisamente por ello las mejores creaciones en los dos casos se resuelven en un dualismo dialéctico entre lo real y lo imaginado o deseado, fruto de la duda agónica última entre razón y fe (en Dios, en el ideal de vida y en el amor) con un resultado en bastantes ocasiones de escepticismo y desengaño.

Anecdóticamente también se puede hablar de un paralelismo en la crítica de los dos autores. Al igual que la obra cervantina sólo comenzó a ser interpretada desde bien avanzada la modernidad, la de Calderón está tardando siglos en verse analizada sin los prejuicios que la tachaban de retrógrada, fría y hasta de cartón piedra, sin olvidar la ausencia de sentido del humor, evidente sinsentido si se atiende a los gestos, respuestas y chistes de muchos de sus personajes capaces de ironizar con los temas más severos. El mismo valor tienen estos juicios que la interpretación de Don Quijote por la ingenua acogida que le propinó su pueblo al verle únicamente como «personaje pícaro y entremesil». Una hondura mayor que la apreciable a primera vista se ha ido descubriendo en los dos tras el velo de las primeras apariencias.

$\mathrm{Si}$ una de las cualidades del arte cervantino fue integrar la cultura popular en el discurso culto, otro tanto se puede decir de Cal- 
derón. Ni uno ni otro se resistieron a dejar fuera del ámbito culto personajes del folklore o ambientes cotidianos y escenas costumbristas. Tampoco renunciaron a presentar alusiones alegóricas en ambientes populares, porque todo ello formaba parte de las fiestas y espectáculos públicos en la realidad del XVII. Wilson ${ }^{25}$ ya señaló la temprana influencia del Quijote en un episodio de El astrólogo fingido con la aparición de Clavileño; pero más interés ofrece la relación del romance La morada de los celos (más tarde resucitada y ampliada en La casa de los celos) sobre La púrpura de la rosa por la predilección de Calderón de esta alegoría cervantina. Desde el primer romance, la descripción de la morada tenía tintes realistas y alegóricos. La casa, una oscura y lóbrega caverna donde soplaba un aire gélido capaz de helar toda alma ardiente, poblada por víboras y serpientes que entraban por las fisuras y grietas, la había identificado Lauso con su propio corazón. Entendía que las víboras eran sus pensamientos que le comían el corazón y al pronunciar el nombre de la amada, el enamorado caía muerto y el romance terminaba.

Trasladada a La casa de los celos, la misma cueva había adquirido ya proporciones alegórico-psicológicas y los personajes mudos iban comunicando su simbolismo gracias a Malgesí. Calderón se apropió esta alegoría en la citada ópera introduciendo sus propias modificaciones (de personajes, música y ritmo) pero conservando el original punto de apoyo alegórico-realista. También la perdida comedia de Calderón Don Quijote de la Mancha, representada en palacio, en Madrid en 1637, podría haber sido un documento (¿quizá solamente festivo?), del interés por el personaje en ese momento temprano y serviría para conocer la opinión de Calderón entonces. Con los documentos que contamos hoy sólo se pueden conjeturar hipótesis. Pero conociendo la trayectoria de Calderón se puede interpretar ese interés dramático por el personaje y pintura de caracteres y ambientes no como un hecho aislado y circunstancial en su obra (hecho realmente inusitado en él) sino como un germen capaz de producir frutos espirituales más profundos. Si le había llamado la atención el caballero de la triste figura no sería únicamente por la popularidad que había adquirido. Junto a la risa y la burla que manifestaba su aspecto en una sociedad deseosa de admirar comportamientos extremos, es fácil pensar que Calderón hubiera descubierto algo más. Muy posiblemente la fuerza de su voluntad y el trágico camino de su existencia fuesen el atractivo mayor del personaje cervantino para un autor empeñado en desvelar el enigma de la existencia, tan complejo y difícil que sólo las imágenes

25 En «Calderón y Cervantes», op. cit., pp. 11-13. 
del teatro y el laberinto podían expresar la dificultad en la que se encontraba el hombre en el mundo.

De lo que no cabe duda es de que Calderón fue el primer gran dramaturgo que tomó en serio a Don Quijote ${ }^{26}$. Aunque la crítica ha observado una mayor presencia de la obra cervantina sobre las producciones de su primera época, lo cierto es que la hondura del pensamiento de Cervantes se diluye en todos los géneros y se mantiene hasta sus últimas producciones aunque en las primeras se puedan seguir mejor sus huellas textuales. El sentimiento trágico que da vigencia al creador del Quijote proviene de la misma fragilidad divisoria entre la realidad exterior y la imagen interior que forja cada uno y que da forma y consistencia a toda la dramaturgia calderoniana.

Desde nuestra perspectiva, nos parece más interesante en la relación de los dos autores el dato no visible a primera vista, el que no procede de la cita textual en sí misma sino el pensamiento común que se descubre en la lectura de la obra. Robert Ter Horst ya nos ofreció una larga lista de obras calderonianas en las que se puede corroborar la presencia de Cervantes. Por su parte, Didier Souiller insistió en algo fundamental, en que Calderón fue un gran lector de Cervantes. Los dos escritores trataron de descubrir las fronteras de la realidad y el sueño y difícilmente podían prescindir del realismo y del idealismo para expresarlo. Sin embargo, lo mismo si está presente la cita textual que corrobora de manera más o menos explícita la huella de Cervantes como si no lo está, hay una serie de temas comunes por los que los dos muestran una clara preferencia y que, si bien forman parte del acervo cultural de la - época, reflejan también unos puntos de contacto ideológicos, estructurales y temáticos difíciles de encontrar entre otros creadores, sobre todo de géneros tan distintos entre sí.

Pero si la narrativa de Cervantes constituye una fuente ideológica primordial que traspasa las estructuras del propio género y se puede integrar en cualquier otro, su teatro también adelanta el punto de mayor interés del creador de La vida es sueño correspondiente a las formas y personajes alegóricos. El propio Cervantes se sintió orgulloso de su aportación como lo confirmó en el prólogo a las Comedias y entremeses ${ }^{27}$ : «Fui el primero que representase las imaginaciones y los pensamientos escondidos del alma sacando figuras morales a teatro, con general y gustoso aplauso entre los oyentes». Precisamente ese ahondar en el alma (aunque sabemos que no fue

26 Véase JACINTO Rivera DE Rosales, Sueño y realidad. La ontología poética de Calderón de la Barca. Hidesheim, Olms, 1998, p. 15.

27 En O. C. de Cervantes, I. Ed. de Valbuena. Madrid, Aguilar, 17 ed., 1970, p. 210. 
el primero en hacerlo) fue el acierto de todo el teatro de Calderón, sentando las bases del teatro de conciencia, incluso en el caso de los autos, pues independientemente del asunto, el argumento se orienta a ese fin y las figuras alegóricas no sólo representan una entidad sensible sino que ahondan en las galerías del alma. Desde ese punto de vista, los autos calderonianos tienen una gran modernidad.

También en el mismo prólogo citado, Cervantes, a modo de cierre y doliente despedida ${ }^{28}$ del lector, alude a una obra que pensaba escribir y cuyo título resume muy bien toda la filosofía de Calderón expuesta sobre todo en los autos: «Y para enmienda de todo esto le ofrezco (al lector) una comedia que estoy componiendo y la intitulo El engaño a los ojos, que si no me engaño, le ha de dar contento» ${ }^{29}$. Aunque no llegó a escribirla, los recuerdos de El retablo de las maravillas, o de las mismas imaginaciones de don Quijote parecían estar cerca de esa obra que, a su vez podía enlazar con uno de los temas preferidos por Calderón.

Sólo el título permite establecer la afinidad de intenciones sobre todo en lo concerniente al carácter moral de los autos, además de la habilidad teatral para desarrollar los juegos escénicos de mayor interés. Por ser además estas creaciones donde mejor esquematizó Calderón todo su pensamiento y arte dramático, las coincidencias no sólo con el teatro sino con la novela de Cervantes pueden tener un valor más relevante que las diseminadas por el resto de su obra.

Una primera cualidad emparenta a los dos autores en cuanto que en los autos siempre se puede encontrar una estructura elemental en donde están imbricados con toda cohesión realismo e idealismo. Como los pícaros y los ascetas, los personajes de su teatro (y no sólo de los autos) avanzan cada uno en una dirección con la carga de su propio yo hacia el fin impuesto (poder, gloria, Dios) evitando los peligros del camino. Sus protagonistas siempre están en movimiento y la expresión sacramental no abandona el mundo de los sentidos por lo que la dualidad correspondiente al esquema dialéctico de amo-criado, soñador-realista, representa el valor del ser en el mundo y el deseo de ser en sí mismo. De esa forma la teoría social de la comedia nueva se ajusta perfectamente a la expresión de la dialéctica humana.

\footnotetext{
${ }^{28}$ Su despedida participa de la misma nostalgia que expresó en el Persiles ("pero no hallé pájaros en los nidos de antaño»).

29 En $O$. C. I., op. cit., p. 211 . Recuérdese que con un título muy parecido se representó en 1622 la comedia Cómo se engañan los ojos. La crítica ha atribuido esta obra a Juan Bautista de Villegas. Apareció impresa en Zaragoza, 1632 con el título completo Cómo se engañan los ojos y el engaño en el anillo. Ver J. E. VAREY y N. D. SHERGold, Comedias en Madrid: 1603-1709. Repertorio y estudio bibliográfico. London, Támesis Book,1989, pp. 84-85.
} 
En los autos se pueden ver desarrolladas unas mismas características coincidentes con las creaciones cervantinas, sin olvidar las propias cualidades originales de su teatro como la insistencia en presentar escenarios con montañas o con la aparición de figuras morales, como Castilla, el Temor, la Sospecha, los Celos, la Curiosidad, la Desesperación en La casa de los celos y selvas de Ardenia y Curiosidad, Lucifer, Costumbre y Comedia en El rufián dichoso. La Enfermedad, la Guerra, el Hambre, España, el Demonio, riachuelos (representados por tres niños) se pueden relacionar con personajes históricos como Escipión y Yugurta en El cerco de Numancia . Más interés ofrece la Fama cuya cualidad de mítica pregonera y compañera habitual del pueblo en su discurso propagandístico hace su aparición en La casa de los celos y El cerco de Numancia. Pero incluso en la comedia de santos La gran sultana se da fin a la obra con el sonido de las chirimías marcando la apoteosis celestial propia del final de los autos.

Creemos que lo más interesante que puede relacionar estrechamente a los dos autores es la convivencia de elementos costumbristas y populares con las figuras alegóricas, en las que se exponen "pensamientos escondidos del alma», como bien decía Cervantes. La Fama es el más completo símbolo de esa simbiosis alcanzada entre lo popular y lo culto por integrar el mito, la alegoría y la noticia de la plaza pública en el sustantivo propio. Desde la primeriza comedia El trato de Argel, se decantó el autor por esta combinación de elementos con los que Calderón en los autos intenta abarcar el universo en un ejercicio de redondez telúrica de la que no prescinde del pequeño mundo interior. Sin embargo hay otras coincidencias que permiten ver la relación estética de los autos con la obra cervantina.

\section{El CONCEPTO DE LA VIDA COMO PEREGRINACIÓN}

Si la vida del hombre en cuanto peregrinación sobre la tierra en busca de su verdadera patria actualizó para el pensamiento cristiano barroco una metáfora de larga tradición, llena de connotaciones morales, también ese contexto por donde discurría el viaje estaba poblado de reminiscencias picarescas que convivían con las más altruistas decisiones. Los innumerables peligros a que se exponía todo viajero y a los que tenía que enfrentarse se identificaron muy pronto con los males que acechaban al hombre para impedirle terminar su viaje en la casa de Dios.

Si con razón se ha podido afirmar que los libros cervantinos son ante todo libros de viaje, y el camino es uno de los términos más 
recurrentes desde el Quijote al Persiles, también se puede decir lo mismo de Calderón (Souiller) porque incluso cuando el personaje descansa o está quieto siempre está caminando su imaginación pues, como dice el Mundo en La nave del mercader, "aunque el Hombre esté dormido/ su deseo nunca duerme». Los dos autores son maestros en crear ficciones de doble tiempo y espacio a partir de dos conciencias integrales y a la vez complementarias que caminan y dialogan. El peregrino en Cervantes no sólo va buscando la verdad y autenticidad de su vida sino el amor que se convierte en objetivo principal del viaje bajo el que se encubre la trilogía mujer, gloria y Dios.

Los personajes de Persiles y Sigismunda y el propio Don Quijote son modelos simbólicos de diversos autos en los que la figura del peregrino resulta un caminante forzado a iniciar el difícil viaje de la vida en busca del amor total. Como los cervantinos, nunca van solos sino acompañados por personajes complementarios con cuyo diálogo avanzan en el conocimiento de sí mismos. Los encantos de la Circe, La segunda esposa, El año santo de Roma, El año santo en Madrid, A María el corazón ${ }^{30}$, La redención de cautivos, El veneno y la triaca, La nave del mercader, El diablo mudo, El indulto general, El primer refugio del hombre y La vida es sueño pueden servir de ejemplo, entre otras muchísimas alusiones que se reparten en una mayoría de piezas, para constatar la preferencia del dramaturgo madrileño por el motivo del camino y por el personaje del peregrino cuyo modelo real si bien procede de Cristo ${ }^{31}$ evidentemente, las sugerencias del personaje quijotesco le permiten actualizar la figura bíblica en un mundo del entorno rural o urbano familiar al espectador y con cuyas aventuras también podía disfrutar por los enredos y aun marañas de la acción.

A veces, como en El gran teatro del mundo, los personajes viven cara al espectador todo el ciclo existencial entre su nacimiento y

30 A propósito de este auto, Valbuena recuerda el juego de palabras que Cervantes expone en el Persiles a partir de las compañeras de viaje que pretenden distraer al peregrino (VALBUENA, Autos sacramentales de Calderón, nota preliminar A María el corazón. Madrid, Aguilar, reed. 1987, p. 1133). Se refiere Valbuena al pasaje en el que Bartolomé cuenta su gran mentira a propósito del robo del que dice haber sido víctima y del que restituye la mercancía al ser reconocido: «aquí señora Constanza, viene el bagaje, con todo aquello que en él estaba, excepto dos vestidos de peregrinos, que el uno es este que yo traigo, y el otro queda haciendo romera a la ramera de Talavera" (en ed. de ValbuenA, Obras Completas de Cervantes. Madrid, Aguilar, 17 ed., 1970, II, pp. 1950-51).

31 En realidad el modelo de Don Quijote bien podía haber sido Cristo. Unamuno y Antonio Machado señalaron su parecido. Este último en Juan de Mairena consideró al personaje cervantino, junto con Platón y Cristo, la referencia fundamental para oponer el solipsismo de la «sofística de la razón humana». 
muerte y otras, como en la comedia La vida es sueño, Calderón hace nacer a la vida a su protagonista tras una existencia entre las sombras de la ignorancia de la realidad. Si desde entonces van juntos en su caminar las dos existencias de Segismundo y Rosaura, les ocurre lo mismo a otros muchos personajes. Teatralmente se sirve de la imagen de la cárcel platónica, de la cueva o gruta y de la ausencia de luz para expresar la falta de vida, normalmente cognoscitiva, como tópicos más recurrentes en sus obras. La salida de esa oscuridad, metáfora del vientre materno, o el disfraz para nacer a una nueva vida, son los recursos más significativos de su teatro y al mismo tiempo los resortes narrativos más peculiares de Cervantes.

Si esa cueva o gruta había sido el objeto figurativo propio del teatro medieval, los dos autores, como los pintores del momento, lo recogen como expresión de un mundo subterráneo, cercano a la muerte de la vida o de los sentidos. Cervantes en La casa de los celos (J. II) hace que Reinaldos busque «a la bella fugitiva», objeto de sus amores, y descubre la boca de la sierpe entre «crujidos de cadenas, ayes y suspiros dentro" (que marca la acotación) en la que un horrible estruendo le hace dudar de la realidad de lo que ve:

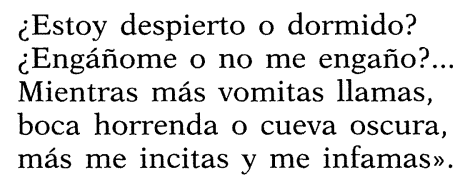

También el disfraz y el cambio de nombre en Don Quijote y en los protagonistas del Persiles, no son meros accesorios accidentales sino formas de nacer e integrarse en una nueva vida por lo que tienen, como en el teatro calderoniano y sobre todo en los autos, una funcionalidad ideológica fundamental. Asimismo, la preferencia por el travestismo constituye un interesante centro de atracción en los dos autores.

\section{El ANSIA DE LIBERTAD, MÓVIL DE TODAS LAS ACCIONES}

Si la realidad del mundo ofrece profundas dudas y la apariencia engaña en la mayoría de las casos, como experimentó muy bien Don Quijote, la realidad del alma en cambio no ofrece dudas para los personajes cervantinos o calderonianos. Aquéllos resumen el valor de la libertad en todos los aspectos (en la persona, en el amor, en la política). Las palabras de Don Quijote representan todo un símbolo del verdadero significado del término: «La libertad, San- 
cho, es uno de los más preciosos dones que a los hombres dieron los cielos; con ella no pueden igualarse los tesoros que encierra la tierra ni la vida; y, por el contrario, el cautiverio es el mayor mal que puede venir a los hombres» (II, cap. LVIII).

Los personajes calderonianos luchan contra todo para conseguir su libertad: contra la naturaleza (estrellas, destino, hado), contra el mismo padre, el rey y toda la sociedad e incluso contra la superioridad divina. El sentido de la tragedia deriva en muchos casos de esa irracional oposición a cuantos obstáculos impiden realizar un sueño individual. Si en muchos dramas el protagonista no consigue su propósito es porque al dejarse llevar por su ansia ciega no ve los peligros y termina cayendo (muerte o simple caída de un caballo) en aquello de lo que huye. El pensamiento racionalista de Calderón también estaba apuntalado por don Quijote, quien contra la opinión de Sancho sobre su particular idea de la Fortuna, sentenciaba desde su mejor racionalismo: «Lo que te sé decir es que no hay fortuna en el mundo, ni las cosas que en él suceden, buenas o malas que sean, vienen acaso, sino por particular providencia de los cielos, y de aquí viene lo que suele decirse: que cada uno es artífice de su ventura» (II, LXVI). Los universales monólogos de Segismundo en favor de la libertad y las encendidas defensas de tantos personajes autoafirmándose en su libertad y voluntad alcanzan un sentido trágico en toda su obra.

En los autos, todos los personajes justifican sus acciones en nombre de su libertad y tanto las fuerzas del bien como las del mal muestran la libre decisión de su voluntad de obrar. Así, en Andrómeda y Perseo, es el Demonio quien pide ser libre; en Los alimentos del hombres, Adamo, nuevo Segismundo, se queja de su condición esclava; en La inmunidad del sagrado el Hombre, encarcelado tras un juicio, sufre el tormento y pide justicia y en La vida es sueño ese ansia de libertad se extiende por los cuatro elementos, desde la tierra al cielo, para mostrar que todo cuanto vive desde la raíz más elemental se une al clamor y la lucha humana por ser primeramente y por ser, además, libres.

\section{SENTIDO ÉtICO DE LOS PERSONAJES: CADA UNO ES HIJO DE SUS OBRAS}

La libertad va unida a la responsabilidad del individuo. Sin dejar lugar a dudas, Calderón lo resumió en el auto La vida es sueño. Cuando la Gracia se aparece al hombre encerrado tras un peñasco y le pide que le siga también le advierte que sólo será lo que su voluntad quiera: 


$$
\begin{aligned}
& \text { Sigue esta luz y sabrás } \\
& \text { de ella, lo que fuiste y eres; } \\
& \text { mas de ella saber no esperes } \\
& \text { lo que adelante serás, } \\
& \text { que ello tu sólo podrás } \\
& \text { hacer, que sea malo o bueno. }
\end{aligned}
$$

Es la misma lección de responsabilidad que enseñaba Don Quijote: "Cuando el hombre hace algún hecho heroico o alguna extraña virtud y hazaña, entonces nace de nuevo, y cobra otros mejores padres y pierde el ser que antes tenía: ayer se llamaba hijo de $\mathrm{Pe}$ dro y nieto de Sancho; ahora se llama hijo de sus obras» (P.I, cap. IV). La discreción es la cualidad que emparenta a todos los personajes que triunfan en los escenarios de Calderón y es asimismo la cualidad ejemplar del héroe cervantino. Su relación con la virtud cristiana queda resumida en la lección ejemplar que da Sabiduría en La protestación de la fe cuando afirma:

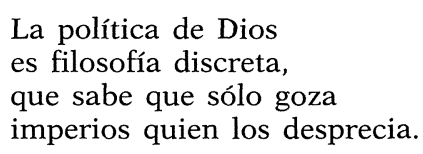

Si los nuevos héroes del mundo barroco van a ser los discretos, como resumió Gracián, término equivalente a virtuosos o lo que es igual, los hombres capaces de despreciar imperios para gozarlos, se entiende que sólo ellos podrán lograr la inmortalidad. En El gran teatro del mundo, la Discreción renuncia a todo para triunfar después. En El maestrazgo del toisón canta la Oración:

$$
\begin{aligned}
& \text { El camino de la vida } \\
& \text { le acertará quien siguiere } \\
& \text { la Oración y la anduviere } \\
& \text { aun antes de la partida. }
\end{aligned}
$$

Esta lección que sabía muy bien el Bueno de Alonso Quijano representaba el sentido ascético del mundo y la capacidad de renuncia por el esfuerzo de "vencerse a sí mismo». Los personajes de Calderón son hijos de sus obras y nadie mejor que ellos han sabido vencerse a sí mismo imponiendo su voluntad. El título de No hay más fortuna que Dios resume una de las direcciones a la que se orientan los héroes de los autos.

Sin embargo, la práctica de la libertad y la voluntad puede derivar hacia la otra dirección, hacia el poder temporal y también son numerosos los ejemplos de estos personajes, simbolizados en Nembroth, reiteradamente citado en escena como prototipo de an- 
sia desmedida de poder y de ejemplo práctico de fracaso para quien siga sus lecciones como ocurre en El valle de la Zarzuela, El sacro Parnaso, A Dios por razón de estado, La torre de Babilonia, La cena del rey Baltasar, Psiquis y Cupido para Toledo y Mistica y real Babilonia.

\section{ENTRE EL SUEÑO Y LA REALIDAD. LAS FRONTERAS DEL CONOCIMIENTO}

Calderón trasladó constantemente a las tablas uno de los problemas que más preocupaba a su generación: el deslindar la realidad de la fantasía. Bajo formas diferentes, entre las que sobresale el sueño en cuanto recurso para confundir al durmiente, siempre temeroso de que se desvanezca todo "como pompa al viento" o se resuelva "en humo, en polvo, en nada», el protagonista de muchos autos vive un doloroso conflicto al no saber distinguir si lo que le presenta su fantasía es sueño, locura, ilusión, mera sombra engañadora o corresponde a la verdad, a la razón. No sólo en el Quijote se producen esas visiones. En El laberinto de amor, por ejemplo, Porcia se muestra confusa al no saber distinguir entre el sueño y la realidad, entre la materialidad de Julia o su forma fantasmal, lo mismo que le había sucedido poco antes también a Julia con sus propias visiones. Incluso el efectismo teatral de esta comedia recuerda a la espectacularidad de los autos en donde se presentan esos juegos de sueño, apariciones y visiones fantasmales que anuncian presagios o advierten a los personajes. El Viático Cordero, Mística y real Babilonia, Sueños hay que verdad son, No hay instante sin milagro, La nave del mercader, El tesoro escondido, La piel de Gedeón y sobre todo La vida es sueño (en donde incluso el tema del tiempo se une a la dramática concepción de la vida como sueño y la posibilidad de entender la muerte como otro más en la mente de los hombres) exponen la ansiedad del hombre por conocer las fronteras de la verdad y de la realidad.

Precisamente en estos casos se potencian los juegos escénicos espectaculares (disfraces, apariciones, enredos) para expresar la dificultad de comunicar el tema. En otras ocasiones, y a veces combinado con el recurso de los sueños o apariciones, se introduce la astrología. En los autos es Luzbel el encargado de representar las mayores especulaciones para el ser humano gracias a sus diabólicas artes y su magisterio en la magia (El pastor Fido). Sin embargo, en la mayoría de los casos los medios de encantamiento utilizados por los personajes calderonianos provienen y actúan desde el mismo ser. Es la conciencia quien se encarga de autoengañarse y apenas necesita la ayuda de fuera (sueños, magos, beleños, Circes 
más o menos disfrazadas) pues le basta con su Inspiración, otro de los personajes que asiste a desarrollar la locura del hombre y provocar su error. En El año santo de Roma se resume el último sentido que debe aprender el Hombre: primero a reflexionar, contando con su albedrío y después a no olvidar que

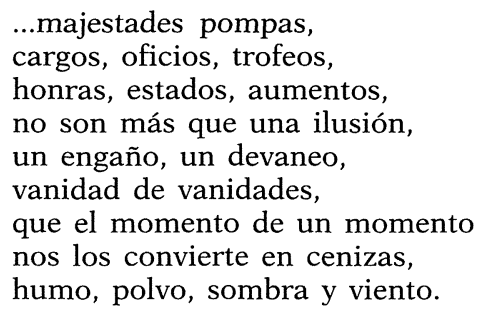

Son varios los autos en que se repite ese último verso a modo de estribillo didáctico que advierte la lección del desengaño.

\section{LA SOLEDAD DEL HOMBRE Y SU EXPRESIÓN DIALÉCTICA. LA PRUEBA}

Teniendo en cuenta que la libertad y la voluntad son individuales e íntimas y que la vida es un viaje cuya andadura depende de la elección personal, la existencia del hombre no puede concebirse si no es en completa soledad. Soledad interior puesto que el mundo se le ofrece como un caos desordenado o un laberinto en donde es fácil perderse. Desde su postura cristiana, como Don Quijote, el Hombre de los autos desea hacer el bien y caminar por la senda adecuada pero de su contacto con la realidad visible y de su reflexión sobre ella nace por un lado el posible pensamiento desviado y por otro, el aferrarse al empirismo de esa realidad. El conflicto se dramatiza cuando tratan de convivir en un mismo sujeto o marco contextual la duda sobre sí mismo, sobre lo demás y la certeza de la fe. La búsqueda de la inmortalidad, como Don Quijote, resulta un esfuerzo ímprobo en cuanto hay que adecuar paralelamente intereses contrapuestos. Sólo un estado de enajenación constante, locura del ideal o de la cruz, permite a los protagonistas sacramentales enfrentarse a todo. Son los monólogos los que mejor comunican el conflicto difícil y de alguna manera preparan las pruebas a las que continuamente se ven sometidos en su caminar.

Desde esa soledad el dramaturgo presenta a veces las dos posibles resoluciones opuestas ante una elección bajo la fórmula dual de dos hermanos o hermanas que van sorteando las pruebas de la 
vida de forma divergente. Es el caso de El laberinto del mundo, El pleito matrimonial, Llamados y escogidos y La torre de Babilonia. En la mayor parte de las obras, sin embargo, la lucha de opuestos se presenta directamente en guerra entre el Bien y el Mal, metamorfoseados en diferentes personajes Angel-Demonio, Luz- Oscuridad, Gracia-Culpa, etc... Pero siempre la dialéctica de la personalidad compleja se desdobla al menos en dos personajes, que de acuerdo con el esquema Don Quijote-Sancho y con la misma tipología que la comedia (señor, gracioso) permiten visualizar las opciones interiores y exteriores. Precisamente destaca el elevado número de ingenuos elementales, parientes de Sancho, que, con el nombre de Inocencia y en otros casos Simplicidad, someten al análisis de la experiencia los ensayos ideológicos de sus señores. Así ocurre en El veneno y la triaca, La vacante general, La semilla y la cizaña, La cura y la enfermedad, El pintor de su deshonra, Las Ordenes militares La redención de cautivos La viña del Señor, El laberinto del mundo (Inocencia), La orden de Melquisedech, El maestrazgo del toisón, El verdadero dios Pan (Simplicidad)

De forma más directa, la aparición de los Sentidos en el escenario, del Mundo y del Ingenio o Pensamiento favorece el conflicto interior directo para dramatizar el problema de la conciencia y la experiencia.

Toda la acción teatral se desarrolla a base de pruebas. La elección del destino resulta un continuo obstáculo en el camino del Mundo, visto siempre como macrocosmos en donde tiene que participar el hombre y salir indemne de sus trampas. Laberinto, teatro, mercado son los términos que mejor resumen la competencia, el engaño y la confusión de la que tiene que triunfar el hombre desasiéndose de sus ataduras a pesar de su atracción.

Pero también en el mundo hay injusticia y los héroes calderonianos muestran su preocupación por imponer la justicia, que había sido norma del caballero andante. Dramáticamente está expresada, como todo su conflicto agónico, por la introducción de personajes extremos que, como el Padre de Familias, frío y autoritario con los hijos, impone su ley y voluntad. No hay más fortuna que Dios, La siembra del Señor, El valle de la Zarzuela, Primero y segundo Isaac, Las espigas de Ruth, La viña del Señor, Los alimentos del hombre, El día mayor de los días son posibles ejemplos en donde la actuación del Padre deja ver la realidad de la condición humana. Como en el capítulo del Quijote con el amo de Andrés, los espectadores reciben el sentimiento de impotencia ante la realidad. En este sentido Calderón prescinde de la ternura que en muchas ocasiones sirve a Cervantes para equilibrar el concepto desengañado del mundo, pero lo compensa con la música y en este 
sentido sus obras, aún las más duras, quedan suavizadas por la constante integración del lirismo musical.

\section{EL AMOR Y LA MUJER. EL RECONOCIMIENTO DE SU DIGNIDAD}

Lejos de ser misógino, como en tantas ocasiones se ha declarado, Calderón respeta a la mujer y la dota de las mismas condiciones que al hombre. Por eso hay personajes femeninos buenos y malos, ansia de poder y honor en Culpas y en Demonios pero puesto que los atributos externos poco valen para definir la condición femenina en los autos, sus móviles, comportamientos y actuaciones no dejan dudas sobre su igualdad en el plano de la conciencia y de la responsabilidad. En cuanto a tópicos burlescos que tenían que expresar los graciosos para hacer reír ${ }^{32}$ poco se puede deducir de ellos si no se ponen al lado de las opiniones más serias emitidas por otros personajes. En No hay más fortuna que Dios la Música interpreta la armonía de los géneros opuestos y reitera la elevada posición de la mujer en cuanto sujeto capaz de alentar la pasión amorosa: «Alábese la Hermosura/ de que si en algún concepto/ el Hombre es pequeño mundo,/la mujer pequeño cielo,/ teniendo en nevada/ esfera de fuego/ flechados los rayos/ del más dulce incendio".

Ejemplos de todo tipo se pueden encontrar lo mismo que las pullas contra el matrimonio puesto que se trataba de una convención social esperada por el público como contrapunto de distensión en la gravedad del tema. Sin embargo, lo más importante y en donde no hay dudas es en la defensa del amor y en su idealización. Por amor salen los personajes en busca de la fortuna y la idealizada belleza femenina asume en los autos diferentes categorías, desde la Gracia, Naturaleza humana, a la Lascivia y Culpa, en una gradación espacial que trata de abarcar todo el cosmos hasta descender a virtudes morales o físicas (Humildad, Hermosura, Malicia).

En todos los argumentos de los autos se establecen, como en las comedias, complicadas redes de intriga en donde el amor juega un papel decisivo. Aparentemente es el móvil teatral y todo lo demás gira a su alrededor. Para alcanzar ese fin y lograr el propósito del enamorado, ella o él, porque aquí toman indistintamente las decisiones unas u otros, se recurre a cuantos efectos escénicos son

32 Calderón defiende la risa lo mismo en los autos que en los entremeses. En El dragoncillo, un diálogo entre el Sacristán y el Gracioso así lo declara precisamente en otra lectura de los vv. 354-60. Ver Obra corta de Calderón. Kassel, Reichenberger, 1989 Ed. de María Luisa Lobato, p. 213. 
necesarios en el código dramático: disfraces, embustes, cambios de personalidad, ocultamientos, silencios, desmayos, caídas, quejas, llantos, etc... A veces la queja amorosa alcanza tonos románticos, becquerianos, como en La nave del mercader pero lo más importante es que la amada, como Dulcinea, resulta más una creación del deseo que un objeto real por lo que se articula como un nuevo camino para profundizar en la conciencia mediante la proyección del yo en el otro.

\section{LA REALIDAD COTIDIANA Y LA CULTURA POPULAR}

Desde otra perspectiva, los autos de Calderón tienen gran relación con la obra de Cervantes. Se puede afirmar que tanto Cervantes como Calderón fueron los más capacitados autores para integrar la cultura popular en las obras más serias. Todos los recursos de la vida diaria (pregones, bandos, cantos, bailes, mercados, refranes, comentarios jocosos sobre las costumbres, burlas) conviven armónicamente con los más cultos en todas las obras de Calderón y sobre todo en los autos. El esquema escénico construido a base de elementos duales (dos elementos opuestos enfrentados entre sí y a su vez cada elemento antagonista acompañado normalmente de un criado cuya misjón es evitar los excesos idealistas o la enajenación del amo) permite una dialéctica constante entre dos mundos contrapuestos en forma completamente eslabonada.

El enfrentamiento entre criado y señor como proyección hiperbólica de la vida social es un recuerdo vivo de la relación Sancho Don Quijote. La ingenuidad del uno frente a la heroicidad del otro conforman una tensión ideológica, vital y dramática que por sí sola permite ahondar en el mundo interior de los personajes. Se pueden multiplicar los ejemplos de esa convivencia ${ }^{33}$.

Además, como Cervantes, o quizá por su influencia, Calderón muestra preferencia por los marginados. Ambientes picarescos, mesones, ventas, que de por sí se justifican por el concepto del camino, no sólo son aludidos sino revividos directamente con todo su bullicio y sus costumbres poco edificantes. Se puede acotar un grupo en donde el lenguaje realista e incluso descarado en ocasiones, propio del ambiente venteril y del entremés, contrasta violentamente en apariencia con el discurso elevado de los demás perso-

33 Baste citar como ejemplo la dualidad Idolatría-Turpín en El arca de Dios cautiva. Mientras la primera planea introducirse en el pueblo con sus sediciosas acechanzas, el criado establece sus propias conclusiones acerca de los judíos a partir de su experiencia cotidiana despreciando problemas más serios: "¿Quién quita al judío que beba/ vino, sino el tabernero,/ según el agua le echa?». 
najes urbanos (el gracioso de El veneno y la triaca llega a expresarse en dialecto sayagués). El año santo de Roma, El primer refugio del hombre y probática piscina, Tu prójimo como a ti, La inmunidad del sagrado, A María el corazón, La nave el mercader.

Cervantes en El rufián dichoso había conseguido dar unidad a los dos mundos antagónicos del realismo exagerado y la espiritualidad sublimada. Los rasgos y expresiones naturalistas descritas por los criados a propósito del ambiente rufianesco de Sevilla en el que se desenvuelve el futuro santo contrastan con la fuerza de las escenas sensuales de las que se defiende y con el camino de perfección ascético impuesto no sin grandes dificultades por Cristóbal Cruz hasta encontrar la vida sobrenatural. Como en muchos autos de Calderón, la música juega en esta comedia un papel fundamental. Las guitarras y sonajas se combinan con danzas bulliciosas y descaradas para celebrar el triunfo profano mientras que las flautas y chirimías anuncian la música celestial ( Música suena;/ parece que es del Cielo, y no lo dudo»). Igualmente la luz y la oscuridad como contraste de colores sirven para educar al espectador ante la dualidad de la existencia.

También los bailes populares (presentes en los entremeses) se insertan en la acción como en A María el corazón; El verdadero dios Pan y en varias ocasiones aparecen gitanos (El viático cordero, Sueños hay que verdad son), ciegos, encarcelados y mendigos que dan a conocer el ambiente urbano degradado en contraste con el mítico espacio natural abierto y libre de montañas y valles.

Sin embargo, entre todos los autos, hay uno que sobresale especialmente cuando se trata de establecer la presencia (callada por una parte y a gritos por otra) de Cervantes. Es El gran mercado del mundo. Si por sí mismo el auto es un mundo abreviado de todo el teatro calderoniano, éste resulta un mosaico completo de cuantas piezas utilizaba su autor para componer una obra dramática, y además en este caso concreto no nos parece aventurado pensar en un homenaje al autor de Don Quijote.

En primer lugar, la elección del mercado como marco de la acción, define el ambiente realista y popular en donde se mueven los personajes. Pero además, esa plaza pública permite, casi como ninguna otra, establecer relaciones y competencias entre el mundo social y el íntimo y aún más entre el mundo del dinero y la conciencia. Las connotaciones cervantinas se multiplican. El transcurrir de los protagonistas (Buen y Mal Genio, hermanos gemelos) hace de toda la obra un viaje, de ida y vuelta, como el de don Quijote, a la casa del padre, en este caso, emplazada en un valle al pie de la montaña.

Buen Genio representa al mismo Don Quijote, capaz de sufrir los más duros sacrificios para ser digno del amor de la joven villa- 
na, Gracia. Entre los distintos caminos que se le ofrecen al salir de la casa paterna opta por el «camino áspero y dificultoso» en lugar del llano elegido por su hermano, igual que el caballero. Sin embargo, el carácter antitético de los hermanos (enfrentamiento dual de la propia conciencia) y complementario de los protagonistas, su recorrido vital envuelto en continua confusión entre la apariencia y realidad, entre su vista y su percepción, y el amor a una mujer como ideal que guía todas las acciones difíciles constituyen el eje más importante de esa coincidencia.

La compañía de su criado Inocencia, cuya virginidad intelectual y moral le permite asombrarse de todo y llamar a las cosas por su nombre tal como se le aparecen a su vista, provoca la risa constantemente y sitúa a su amo en una posición muy alejada de las normas de comportamiento social haciéndole parecer un auténtico loco. Como don Quijote, su locura procede de su mundo interior y está asentada en una lógica interna que le impide disfrutar de las atracciones, placeres y alegrías que los demás sienten como tales para no renunciar a valores más elevados. Su contraste con el hermano que se limita a comportarse como los demás, admitiendo placeres y riquezas, se hace más exagerado al ubicarse la acción en el mercado. Por eso, cuando se aparta de las mercancías valiosas y compra enseres de humildad y pobreza rechazando los valores codificados por. la sociedad como positivos (joyas, riquezas, belleza, adornos) el nuevo Sancho, ya sin palabras para definir a su amo recurre a la ironía que deja más al descubierto si cabe la enajenación del Bueno.

Además, el desengaño final de Don Quijote correspondiente al triunfo de su ideal se ve bien marcado con el engaño de la realidad que sufre definitivamente Mal Genio y el fin feliz del Buen Genio. Este tiene que desengañarse continuamente en el mundo para conseguir el ideal y aquél, ilusionado constantemente con las apariencias del mismo, termina totalmente desengañado. Siempre el desengaño se erige en centro del hombre y en su constante compañía (en vida y en muerte). Incluso se puede apreciar en el auto, desde una perspectiva humana, la doble tendencia cervantina hacia el "anhelo de Fama y triunfo del Desengaño» que polariza el Quijote.

A la luz de Gracián y del valor de su alegoría, no es difícil encontrar un paralelismo entre la actitud de Buen Genio (cuyas connotaciones con el apelativo de Alonso Quijano no son difíciles de ver, porque en último término tampoco está lejos del héroe cervantino la imagen de Cristo) y Don Quijote. Ambos coinciden en ser «hombres eminentes», según el auténtico sentido de la virtud y sólo por ella se les permite acceder a la «isla de la inmortalidad» 
haciéndoles merecedores de la Fama. En este sentido, la virtud de don Quijote no sólo le llevaría a una inmortalidad religiosa sino también humana. Cuando al final del otro peregrinaje, el de Andrenio y Critilo, los personajes llegan a la isla de la inmortalidad, después de pasar por la "Cueva de la Nada», el portero les informa allí de quiénes pueden acceder a tal isla (discretos, valientes, virtuosos) y las palabras encendidas de Mérito no dejan dudas acerca de la selección de los elegidos: «Desengañáos que aquí no entran sino los varones eminentes cuyos hechos se apoyan en la Virtud, porque en el vicio no cabe cosa grande ni digna de eterno aplauso. ¡Venga todo jayán! ¡Fuera todo pigmeo! No hay aquí mediocridades: todo va por extremos".

A partir de esta interpretación de Gracián puede deducirse fácilmente la proximidad entre la inmortalidad humana y la cristiana. La virtud del propio esfuerzo (enseñanza moral) permite aspirar a una recompensa tan legítima (en el auto el mayorazgo) como la esperada por el comportamiento que condiciona un premio o castigo eterno (enseñanza religiosa). El didactismo moral del auto conlleva estas dos posibles lecturas. De cualquier modo, el amor a la vida, a la mujer (Gracia) no está reñido con el anhelo de inmortalidad. Tampoco el sentimiento del desengaño ante las riquezas del mundo condiciona un nihilismo pasivo. Más bien todo lo contrario. Su extremosidad causa la lucha íntima, la verdadera agonía del ser humano actualizada por Unamuno en nuestro siglo precisamente a partir de los ejemplos de Cervantes y Calderón, máximos representantes para él de la filosofía española. El origen de la constante actividad de Don Quijote y la del Genio Bueno calderoniano radica en la necesidad de hallar una meta compensadora del camino «áspero y dificultoso» que se trazaron para conseguir su fin y ser merecedores del amor de Dulcinea y Gracia respectivamente.

Pero hay otros detalles y circunstancias más concretas que aproximan este auto a Cervantes. Uno de ellos y el más evidente es la presencia de Pedro de Urdemalas con los mismos cambios de disfraces y personalidad que el personaje del folklore revivido en la novela cervantina del mismo título. El hijo de la piedra, urdidor de malas artes no descansa aquí tampoco. Calderón transforma a la Culpa en mujer vengadora y ésta se introduce en el espíritu de ese héroe cuyas habilidades proteicas son suficientemente conocidas para el público:

malas costumbres sembrar solicito en cuantos vivan, urdiendo telas de engaños de que los hombres se vistan; con que mi nombre será. 
mas no importa que lo diga, que de Pedro, y de urdir malas costumbres ello se explica.

Pasa a ser, como el de Cervantes, mozo de mesón, bien versado en los negocios de las ventas aprovechando su fino conocimiento de la psicología humana:

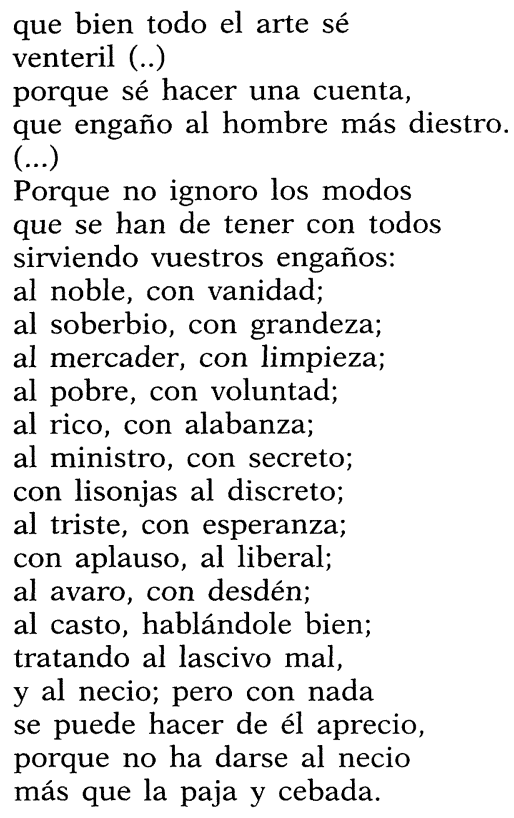

Si como tal actúa y aún se hace pasar por una ventera dispuesta a servir a los clientes en todo lo que pidan (casa, comida, cama y placer) después pasa a ser mozo de ciego, constante embaucador y finalmente gitano. Su actividad le impide el sosiego y como en la comedia cervantina, en el auto es capaz de crear un segundo teatro por sí mismo gracias a sus transformaciones y constante acción ( Yo no puedo estar parado»). Así, como mozo de ciego («yo seré mozo de ciego»), acompaña al. Apetito y se hace pasar por pobre ( «dad limosna a un pobre ciego») para buscar la caridad de los demás y conseguir reducir, aunque sea por una buena intención, la voluntad del peregrino. Junto a Gula, el Pedro de Urdemalas calderoniano intenta por último atraer por la fiesta y el placer a sus víctimas y para ello se disfraza de gitano, "gitano de los sentidos», capaz de conquistar el alma de cualquiera, como dice la Reina a propósito de la compañera (Belica) del cervantino («y a cualquier alma conquista/ y está su fuerza en ser vista»). En el auto, el 
placer gitano se define como ladrón de los sentidos («pues puedo robarlos con mis sentidos») y a tal propósito trata de vender un caballo al Buen Genio, recuperando así Calderón todo los tópicos sociales que circulaban por el pueblo acerca de esta raza marginada.

El famoso montañés se instala en el auto travestido previamente de hombre siendo antes mujer (Culpa) y su actividad proteica resulta arrolladora desde el momento en que Culpa, enloquecida por los celos, decide vengar su honor tras la humillación que sufre al ser despreciada por los dos hermanos. Sin embargo, como el cervantino, cuando ve su fracaso huye de su forma y prepara otra nueva para triunfar en la siguiente aventura.

Ya de gitano, y en unión de otros canta, baila y zapatea una danza tan popular y gustosa a Cervantes como el canario ( Canario a bona, / arrofaifá / si mi padre lo sabe / matarme ha»), introducido en sus entremeses (El rufián viudo). Por cuatro veces en el auto, algo verdaderamente original en cuanto a su insistencia, los gitanos danzan y cantan esta tonada, mostrando el ritmo ( ${ }_{i} \mathrm{Ea}, \mathrm{Pe}-$ rico, otra vüelta») que resulta único entre todos los autos. Perico, como Belisa, en Pedro de Urdemalas, son impulsados al baile con el mismo grito de animación («Ea, Belica, flor de abril») por parte de sus respectivos compañeros gitanos. Lo llamativo de este auto es que la danza del canario tan repetida aquí nunca volvió a ser utilizada por Calderón en otro auto y no hemos visto que ningún otro autor utilice este baile en una obra sacramental (salvo en Lope de Vega en La Araucana), por su carácter peculiar más propio de entremeses que de piezas serias.

Sin embargo, su reiterada presencia aquí junto a Pedro de Urdemalas no parece una mera coincidencia. Asimismo, la atracción por el mundo popular recreado en los gritos de los mercaderes, en el colorido y movimiento de las tiendas, en el mercado y el ambiente de la vida urbana, las ventas y mesones de los caminos con la presencia de la Maritornes correspondiente (Culpa) acechando sin piedad en sus constantes insinuaciones al ascético peregrino y la amena participación de los gitanos pintados con afecto a través de sus alegres cantos, tan presentes en Cervantes, así como la aparición de la Fama como personaje que abre la escena (utilizada también por Cervantes ${ }^{34}$ en La casa de los celos y en la tragedia Numancia), además del uso del pregón entre otros recursos populares, en un ambivalente juego de idealismo y realismo bajo el que se asocian los elementos religiosos y dogmáticos, no puede inter-

34 Buena y Mala Fama son personajes de La casa de los celos; La Fama lo es de la tragedia Numancia. 
pretarse sino como un (consciente o inconsciente) homenaje al autor del Quijote.

Esa preferencia por el mundo venteril del que Calderón muestra un gran conocimiento y por los personajes pródigos (la novela El celoso extremeño tiene también por protagonista otro pródigo) que permiten situar a los héroes de los caminos a la intemperie de todas las dificultades es paralela a la de Cervantes. También la introducción de expresiones coloquiales y refranes populares tan del gusto cervantino se encuentran perfectamente representados en este microcosmos artístico. Pero hay también otros interesantes detalles que muestran la afinidad y coincidencia entre los dos. Así, la preocupación por los problemas económicos tan patentes en la época de los que Cervantes ya se había hecho eco se deja sentir en este auto. Cuando Culpa, vestido de pobre pide limosna, Mal Genio se la niega y se enfrenta a él con duras palabras:

$$
\begin{aligned}
& \text {...No quiero } \\
& \text { que mendigos holgazanes } \\
& \text { lo sean con mi dinero. }
\end{aligned}
$$

De manera semejante, Cervantes en Los baños de Argel se había quejado, por boca de Don Fernando, de los que utilizaban toda clase de embustes para engañar y obtener dinero sin trabajar:

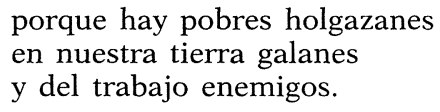

Los dos autores mostraron un mismo interés por los temas económicos cuya complejidad y dificultad para armonizar la ganancia con la conciencia cristiana fue objeto de un amplio tratamiento por parte de moralistas ${ }^{35}$, filósofos y políticos de fines del XVI y principios del XVII. En este auto el vocabulario económico tiene una presencia relevante desde el título. En su interior hay toda una aplicación práctica y simbólica de la política económica tal como la

35 Entre las numerosas obras que se editaron sobre la relación entre la economía y la moral se pueden destacar las de TOMÁs DE MERCADo, Summa de tratos y contratos de mercaderes y comerciantes, que tuvo extraordinario éxito desde su primera edición en y la de MATEO LÓPEZ BRAVO, De rege et regendi ratione (traducida por su hermano y de la que hay una moderna edición con un estudio preliminar de Henry Mechoulán en su trabajo titulado Mateo López Bravo. Un socialista espanol del siglo XVII. Editora Nacional, Madrid, 1977), cuya primera edición de 1616 fue ampliada once años después. Este último dedicó uno de sus capítulos a criticar la ociosidad indicando entre las diferentes formas de ocio negativas para la sociedad la mendicidad, la maestría en engañar, el fingimiento de nobleza, etc. 
desarrollaron autores tan influyentes en la época de Cervantes y Calderón como Tomás de Mercado, Cellórigo y Azpilcueta. Los términos más utilizados en la época por aquéllos cobran nueva vigencia polisémica en el auto. Así, todo un mundo mercantil abreviado se concentra en esta obra: mercado franco, jueves, día feriado, mayorazgo, ganancia, feria, cobrar, comprar, vender, caudal, mercadería, mercar, precios, moneda, dinero, fiado, maravedís, costa, adquirir, bienes, herencia, tratar, contratar, costar, precio, liberal, robar, gastar, tienda, corredor de tienda, despachar, marchante, perder, cuenta, balde, etc...

Se dan además otros detalles anecdóticos que si aisladamente no tendrían otro interés, sumados a los más importantes muestran una coincidencia bastante sugestiva por lo menos. Es el caso de la pintura de la Soberbia cuya descripción coincide con la de un personaje del Persiles. En El gran mercado se nos informa primero de la apariencia de este personaje gracias a la acotación : "Sale la Soberbia con un sombrero de plumas en la mano y una pieza de tela como cogida» y después, en la acción, a la pregunta del Mundo sobre lo que va a vender en el mercado, ella contesta: «Las ricas telas y las ricas ${ }^{36}$ plumas». Estas mismas prendas, atributo de la Soberbia, se corresponden con las que lleva puestas Isabela Castrucho y que tanto llaman la atención de los caminantes como relata el autor: «Estando en esto, vieron venir por el camino, y pasar por delante de ellos, hasta ocho personas a caballo, entre las cuales iba una mujer sentada en un rico sillón, y sobre una mula vestida de camino, toda de verde, hasta el sombrero que con ricas y varias plumas azotaba el viento».

Asimismo, la música que corrobora en el auto la alegría de los vendedores del mercado cada vez que se ha realizado una compra en su respectiva tienda con el reiterado estribillo ( Sea norabuena, $/$ norabuena sea»; «Norabuena sea,/ sea norabuena...»; Sea norabuena,/ norabuena sea,...; «Sea norabuena,/ norabuena sea») reproduce el mismo esquema utilizado por Cervantes en La casa de los celos para mostrar el contento popular. Allí, Lauso, acompañado de Corinto y Clori cantan repetidamente la misma melodía como final de una letra alegre: «¡Norabuena sea!» ...; «Norabuena sea!... ¡Norabuena sea, sea norabuena!»

Finalmente, habría que destacar la similitud entre la pintura de la cueva de los celos cervantina (descrita en el romance del mismo título y en La casa de los celos) y el corazón de Culpa herido por los celos. Las «mil víboras» y "ponzoñosas culebras» de aquella cueva, «vivo traslado» de lo que encerraba el pecho del pastor en

36 También aparece con la variante de «rizas». Ver v. 857. 
el romance anterior, vuelven a instalarse en las mismas entrañas de Culpa en este auto:

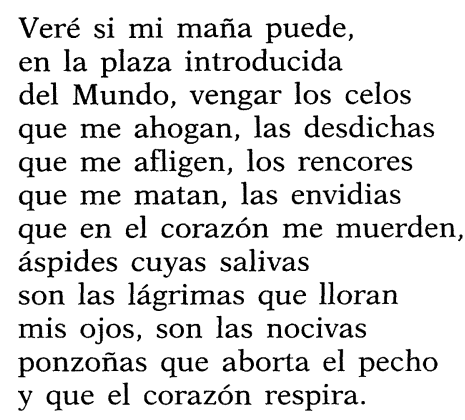

Difícilmente puede encontrarse otro auto calderoniano en donde se den reunidos tantos motivos propios del mundo cervantino como éste de El gran mercado del mundo, pieza además totalmente original en relación con los demás del dramaturgo madrileño justamente por la coincidente acumulación de ecos y recuerdos del autor del Quijote.

ANA SUÁREZ MIRAMÓN

U.N.E.D. 